\title{
Assessing the Presence of Heavy Metals in the Area of Glloogoc (Kosovo) by Using Mosses as a Bioindicator for Heavy Metals
}

\author{
Naser Bajraktari', Ilir Morina', Skender Demaku²* \\ 1 Faculty of Agroecology and Agroenvironment, University of Peja "Haxhi Zeka"St. UÇK 30000, Pejë, Kosovo \\ 2 University of Pristina "Hasan Pristina", Faculty of Natural Sciences and Mathematics, Department of Chemistry, \\ str. "Nëna Tereze" nr. 5, 10000, Pristina, Kosovo \\ * Corresponding author’s e-mail: skender.demaku@hotmail.com
}

\begin{abstract}
This study aimed at determining the level of pollution from heavy metals that are deposited from air in the area of Gllogoc. The main goal was to identify the emission sources of pollution by using mosses as bio indicators. In this study area, the mining of Fe-Ni (Industrial Ferronickel Complex) is believed to strongly influence the level of heavy metals. The mining and production activity of Fe-Ni affects the soil, water and air. As the air pollution (from liberated aerosols of Industrial Ferronickel Complex) and the deposition products of this pollution are harmful not only locally but also can pollute the environmental at extended distances, the use of mosses allows analyzing the content and origin of the pollution from heavy metals. ICP was used for the determination of heavy metals in moss samples. The use of Principal Component Analysis (PCA), dendograms and other statistical procedures, permitted to understand the source of the air pollution from heavy metals.
\end{abstract}

Keywords: heavy metals; $\mathrm{Pb}$ and $\mathrm{Zn}$ concentrates; mosses as bio indicators; soil; water; sterile; sludge; landfill; "Ferronickel" complex

\section{INTRODUCTION}

The main possible pollution source in this area, i.e. the Ferronickel complex, performs the technological processing of the Fe-Ni containing ore; thereby, it produces large amounts of waste that contains heavy metals and other compounds [Barandovski et al., 2013]. The inorganic parts of these pollutants are largely released into the atmosphere, not only by the Ferronickel complex but also as a result of other human industrial activities [Nriagu and Pacyna 2001]. Therefore, evaluating and monitoring the air pollution is mandatory.

The dust generated by the various technological processes that involve combustion in the Ferronickel complex is transported from the wind even at distant distances, polluting the air with various toxic elements that can be deposited in matter during their activity. In this context, the use of moss as bio indicators is a scientifically established procedure for monitoring the deposition of heavy metals from air [Canbay 2017, Walker et al., 2003]. These plants have no roots, meaning that the presence of the pollutants in them is directly related to their presence in atmosphere [Khare 2012]. The level and extent of the air pollutants depends on: emission composition, atmospheric and topographic conditions. Most of the pollutants remain near their discharge source, but some may even spread thousands of kilometres away from the pollution source [Vasconcelos et al., 1998]. The surface and groundwater pollution in this area occur as a possible result of the untreated industrial wastewater originating from the underground discharge pipelines of the Ferronickel complex that flows directly into the local river. In addition to this, the water pollution is also influenced by the urban pollution and discharges of landfill and sterile dumps [Vukojeviç et al., 2010] that lie near the river bank. Likewise, the contamination of the soil occurs as a result from the industrial discharges of the Ferronickel 
compound, and also from the use of pesticides and herbicides in agricultural lands and wastelands [Lazo et al., 2013]. The Earth itself serves as an environment where the continuous deposition of various inorganic and organic pollutants occurs [Mazzoni et al., 2012].

\section{MATERIAL AND METHOD}

The Hypnum cupressiforme moss was used for the research purposes. This type of moss absorbs metals from the atmospheric deposition better than other species [WHO. Regional Office for Europe, 2007].

\section{Sampling}

In order to obtain complete information on the air pollution levels, a concept map was built (a sampling network) that considered the following: a) specific pollution sources, main roads in the city, the field of urban disposal waste, or different factories and plants; and b) geographical and meteorological features related to the terrain of the area, and wind direction. This strategy of sampling is based on the European program of evaluation of heavy metals [Chen 2017, Fernandez et al., 2002]. The samples are collected about $150 \mathrm{~m}$ from the main roads, $100 \mathrm{~m}$ from the local roads, and 200-300 $\mathrm{m}$ from the inhabited areas (villages) Figure 1. The collection is carried out on open lawns and in the spaces between the forest trees, in order to avoid the effect of various tree crowns on the atmospheric deposition.
Each sample is provided by 3 or 5,6 or 10 sub-samples, collected in a $50 \times 50 \mathrm{~m}$ space, [Canbay H.S, et al., 2017] randomly. Submasters are mixed, forming the representative sample of each station. The samples collected were cleared in advance from foreign materials such as; soil, mix other lichens or mosses, herbs, leaves, trees or other, [Barandovski et al., 2013]. They were then put in paper envelopes and sent to the lab for further processing.

\section{Preparation of samples}

The samples obtained in the field, after being thoroughly cleaned in the laboratory from other inert materials, were are dried at the temperature at $30-40^{\circ} \mathrm{C}$ for 48 hours [Canbay and Doğantürk 2017].

The green and brown parts of moss were used for analysis (they represent a period of 1-3 years of growth), so that they reflected the air metal deposits of the last three years. In order to reduce the volume of samples and to carry out homogenization, [Vukojeviç et al., 2010] the samples were hand-crushed, wearing polythene lab-free, dust-free lab coats.

\section{Dry chemical treatment of mosses}

About $0.5 \mathrm{~g}$ of the homogenized moss samples were placed in semi-press Teflon tubes, to which $10 \mathrm{ml}$ of $\mathrm{HNO}_{3}$ were added, [Canbay and Doğantürk 2017] (Merck for analysis) - (9:1). The tubes were plugged and left at room temperature for 48 hours. The temperature aftwerwards

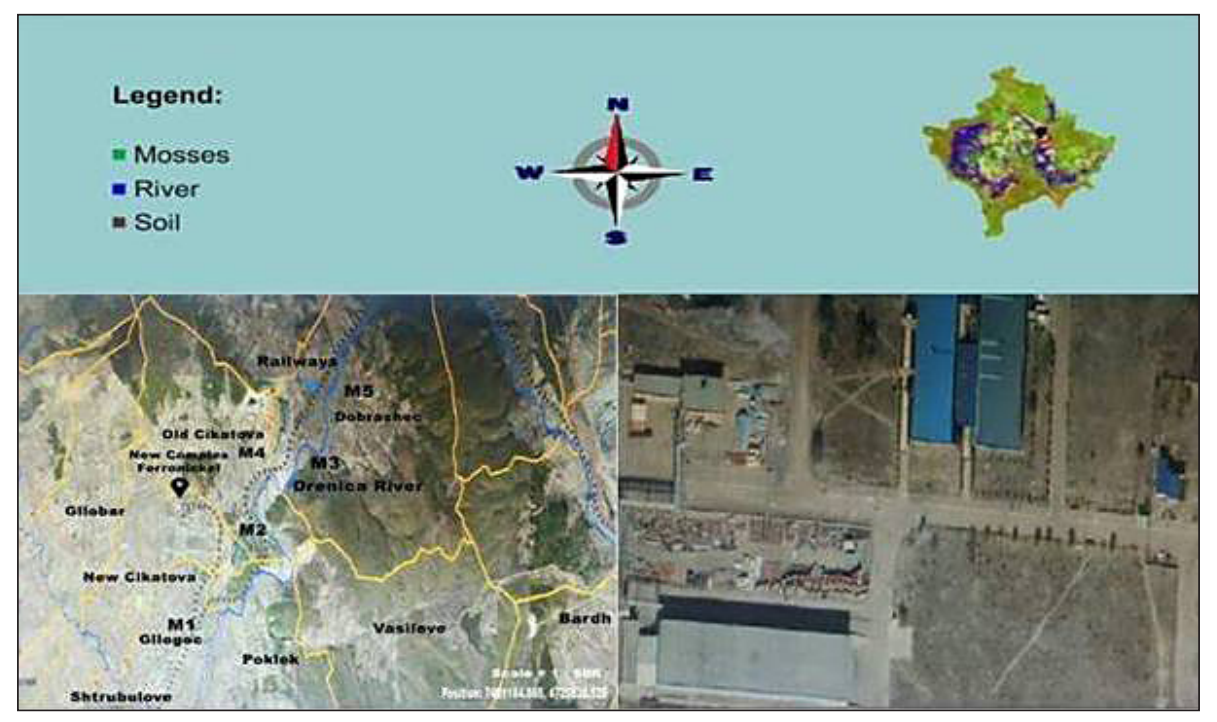

Fig. 1. The sampling sites for collection of mosses. 
was increased to $200^{\circ} \mathrm{C}$ for 1 hour in order to complete decomposition [Barandovski et al., 2013]. The content of the tube is evaporated until a very small volume remained. After the cooling, the samples were filtered and transferred to a normal container with the volume of $100 \mathrm{ml}$.

\section{RESULTS AND DISCUSSIONS}

The results for the heavy metal content in five different sampling positions (the samples taken in July 2016) [Barandovski et al., 2013] measured by ICP-OES are presented in the Table 1 . The maximum values for heavy metals are as follows: $\mathrm{Fe}>\mathrm{Ni}>\mathrm{Zn}>\mathrm{Cu}>\mathrm{Cr}>\mathrm{Pb}>\mathrm{Co}$.

In order to gain an understanding about the possible source of the analyzed heavy metals, the regression results between the studied heavy metals were presented in Table 2. There is a strong positive correlation (presented in yellow) between the metal couples: $\mathrm{Cr} / \mathrm{Co}, \mathrm{Fe} / \mathrm{Co} / \mathrm{Cr}, \mathrm{Ni} / \mathrm{Co} / \mathrm{Cr} / \mathrm{Fe}$ and $\mathrm{Zn} / \mathrm{Co} / \mathrm{Cr} / \mathrm{Fe} / \mathrm{Ni}$; suggesting that these metals originate from the ultra basic rocks which are rich in iron and also contain nickel, cobalt, zinc and chromium [Ference et al., 2016]. There is no correlation for $\mathrm{Pb}$ and $\mathrm{Cu}$ suggesting a different source from the $\mathrm{Zn} / \mathrm{Co} / \mathrm{Cr} / \mathrm{Fe} / \mathrm{Ni}$ group.

In order to gain a better understanding about the heavy metal contents in between the sampling positions we created a dendogram for all of the sampling positions (Figure 2). The maximum similarity was found between the M2/M5 sampling positions, followed by M2/M4. Sample M3 is distinctive in regard to its chemical composition. In this context, this sample represents a possible external impact that is caused from a pollution source. This sampling position is situated near the deposited landfill of the Ferronickel Complex.

In order to better understand the differences concerning the regression results (Table 1) the Principal Component Analysis
(PCA) was performed [Hyang et al., 2007]. PCA is a multivariate statistical method, originally proposed by Hotelling.

The differences among the heavy metal (Figure 3) content are explained using the first two components of the Scree plot. On the basis of the principal component scores, PCA is able to examine multivariate relationship and explain the variance in the data while reducing the number of variable to several groups of individuals [Everitt et al., 1992]. The PCA results are presented in Figure 3 (the Scree plot) and Figure 4 (loading plot).

The PCA analysis groups the heavy metals into two major entities: first group ( $\mathrm{Fe}, \mathrm{Zn}$, $\mathrm{Co}, \mathrm{Ni}$ and $\mathrm{Cr})$ and second group $(\mathrm{Cu}, \mathrm{Pb})$. This confirms the results from the regression analysis (Table 1), meaning that these two elements $(\mathrm{Cu}$ and $\mathrm{Pb}$ ) have a similar source from pollution. The concentration of heavy metals in the analyzed moss samples reflects the atmospheric deposition of the heavy metals [Lucaciu et al., 2004]. In addition to the part of pollution from directly affected areas, the contaminated dusts adsorb the slag and sterile particles as well as the aerosol particles discharged from the forest of the plant, thereby increasing their content on the moss samples [Vasconcelos et al., 1998]. Moreover, these dust particles can enter soils with other metallic particles, from the flow of the nearby river entering the groundwater layers. The other published results [Barandovski et al., 2013] indicate that this area around the Ferronickel plant is highly polluted with heavy metals.

The concentration of heavy metals in moss samples is as follows: $\mathrm{Fe}-629+6736 \mathrm{mg} / \mathrm{L}$; $\mathrm{Ni}-$ $12.30-132.50 \mathrm{mg} / \mathrm{L} ; \mathrm{Cu}-1.20-103.20 \mathrm{mg} / \mathrm{L}$; $\mathrm{Zn}-27.50-106.40 \mathrm{mg} / \mathrm{L} ; \mathrm{Co}-1.59-7.57 \mathrm{mg} / \mathrm{L}$; $\mathrm{Cr}-0.20-17.74 \mathrm{mg} / \mathrm{L}$ and $\mathrm{Pb}-0.00-15.99 \mathrm{mg} / \mathrm{L}$. The content of $\mathrm{Pb}$ is quite high, compared to the moss sample analysis performed in other countries (Table 3) [Lazo P, et al., 2013].

Table 1. Heavy metal levels in mosses samples determined by ICP-OES

\begin{tabular}{|c|c|c|c|c|}
\hline Variable & Mean & Minimum & Median & Maximum \\
\hline $\mathrm{Co}$ & 4.23 & 1.59 & 4.00 & 7.57 \\
\hline $\mathrm{Cr}$ & 7.66 & 0.20 & 8.79 & 17.74 \\
\hline $\mathrm{Cu}$ & 24.40 & 1.20 & 5.60 & 6736.00 \\
\hline $\mathrm{Fe}$ & 2527.00 & 629.00 & 1957.00 & 132.50 \\
\hline $\mathrm{Ni}$ & 71.50 & 12.30 & 75.30 & 15.99 \\
\hline $\mathrm{Pb}$ & 7.31 & 0.00 & 6.19 & 106.40 \\
\hline $\mathrm{Zn}$ & 54.50 & 27.50 & 40.60 & \\
\hline
\end{tabular}




\section{CONCLUSIONS}

In this study, several metals (Fe, Zn, Co, Ni, $\mathrm{Cr}, \mathrm{Cu}$ and $\mathrm{Pb}$ ) were analyzed in the moss samples with the statistical methods. The following conclusions were drawn from the discussions above: (1) The difference in the content of the metals in the moss samples in strongly influenced by the local pollution source (Industrial Ferronickel Complex); (2) The correlation coefficients of the metals (between $\mathrm{Zn} / \mathrm{Co} / \mathrm{Cr} / \mathrm{Fe} / \mathrm{Ni}$ ) in the moss samples were between 0.860 and 0.947 . This indicates that these metals have a common geological source (from ultra basic rocks). The absence of correlation between $\mathrm{Cu}$ and $\mathrm{Pb}$ points out that they are directly related to a possible

Table 2. Regression results for the heavy metals in the studied sampling positions

\begin{tabular}{|c|c|c|c|c|c|}
\hline Co & $\mathrm{Cr}$ & $\mathrm{Cu}$ & $\mathrm{Fe}$ & $\mathrm{Ni}$ & $\mathrm{Pb}$ \\
\hline 0.914 & & & & & \\
\hline-0.196 & -0.557 & & & & \\
\hline 0.941 & 0.912 & -0.229 & & & \\
\hline 0.986 & 0.912 & -0.246 & 0.882 & & \\
\hline-0.126 & -0.106 & -0.113 & -0.391 & 0.036 & -0.403 \\
\hline 0.909 & 0.933 & -0.42 & 0.947 & 0.86 & \\
\hline
\end{tabular}

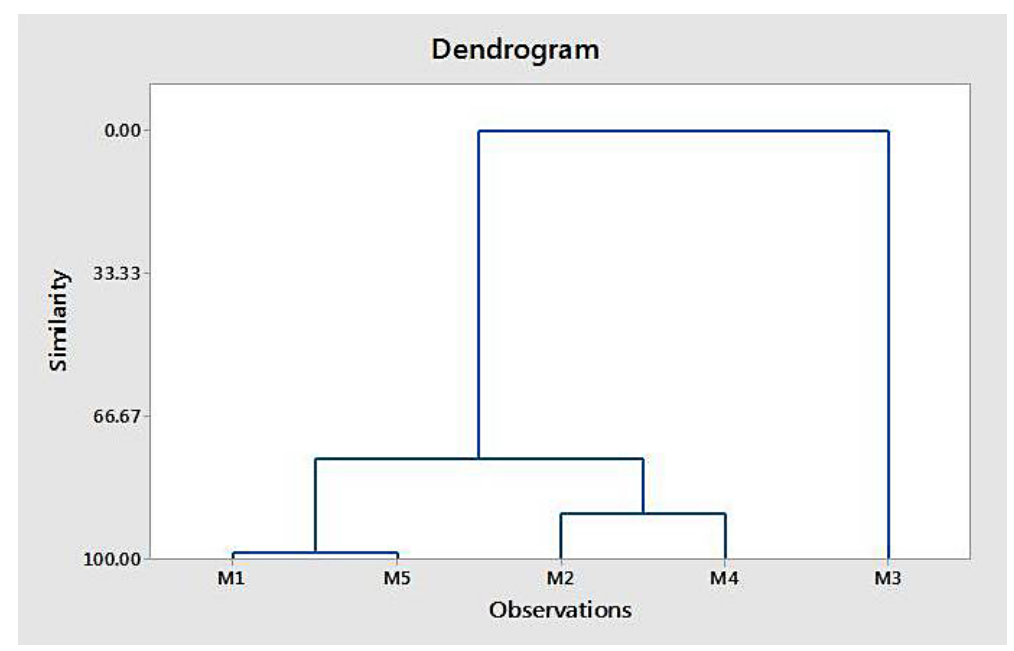

Fig. 2. Dendrogram of cluster analysis of the heavy metals in moss samples at five sampling positions

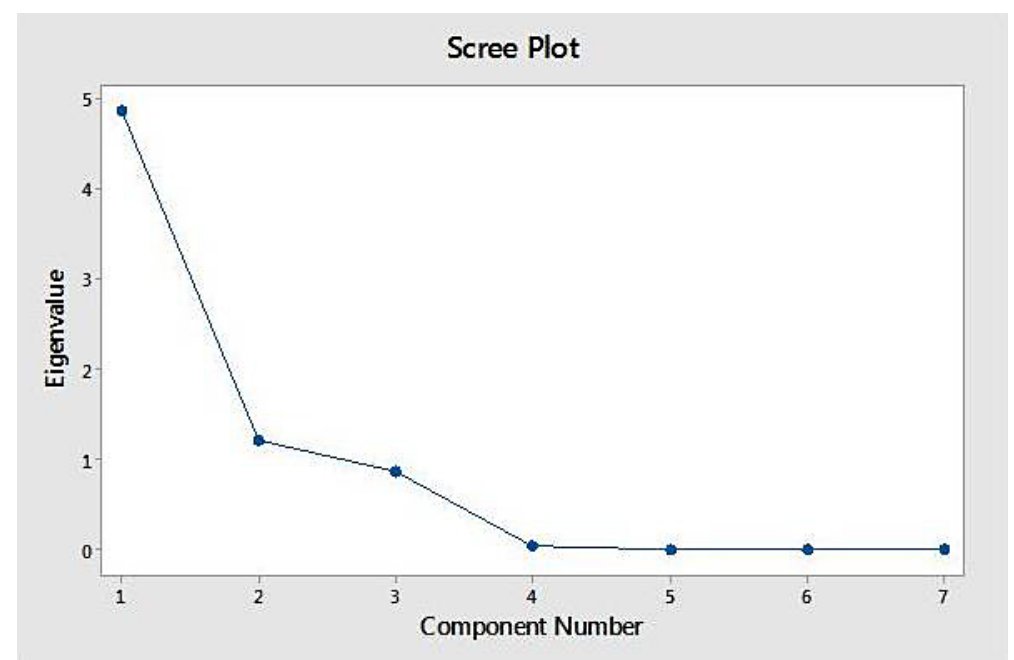

Fig. 3. Scree plot. 


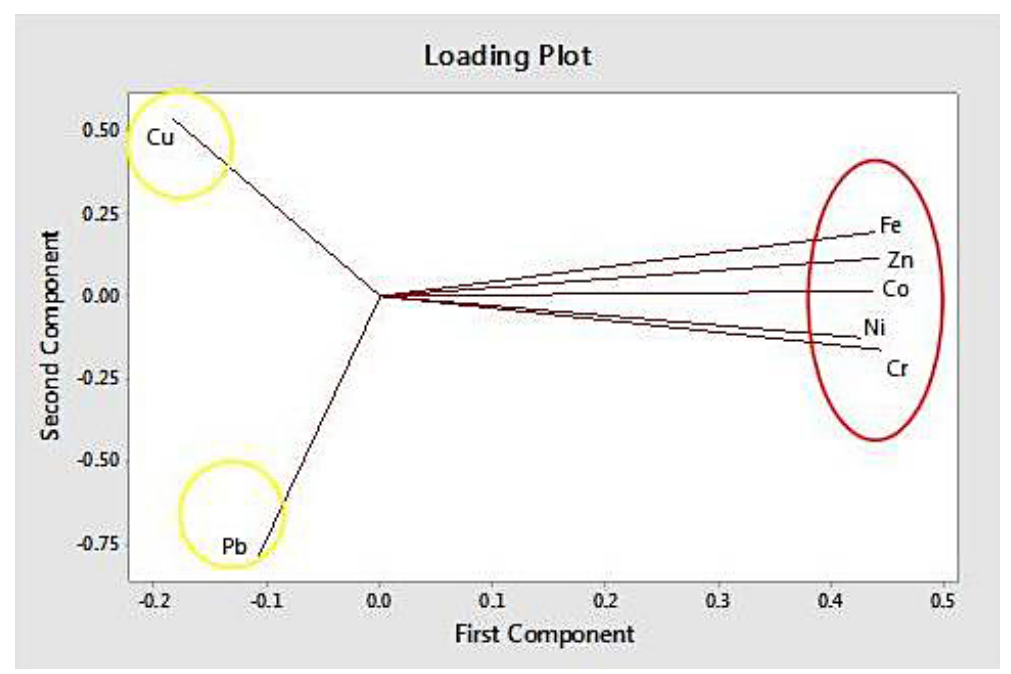

Fig. 4. PCA ordination biplots for the analyzed heavy metals in moss samples

Table 3.The range of variation of lead in moss samples of the area in the vicinity of the Ferronickel complex (Kosovo) and some other countries (* Ref. [Lazo et al., 2010])

\begin{tabular}{|l|c|}
\hline \multicolumn{1}{|c|}{ Country } & $\mathrm{Pb}, \mathrm{mg} / \mathrm{kg}$ \\
\hline Kosovo (Ferronickel Complex, this work) & $0.00-15.99$ \\
\hline Macedonia * & $1.50-37.20$ \\
\hline Albania * & $1.34-5.38$ \\
\hline Croatia * & $0.06-82.40$ \\
\hline Romania* & $6.45-31.5$ \\
\hline Norway * & $0.64-6.12$ \\
\hline
\end{tabular}

local pollution source; (3) The first principle component groups the metals in two categories: a) $\mathrm{Fe}, \mathrm{Zn}, \mathrm{Co}, \mathrm{Ni}, \mathrm{Cr}$; and b) $\mathrm{Cu}, \mathrm{Pb}$. This supports the regression results, confirming their pollution source. Generally, the above-mentioned results were able to show the metal pollution distribution within the different sampling positions. The study confirms that the use of moss can serve to monitor the heavy metals.

\section{REFERENCES}

1. Everitt B.S. and Dunn G., 1992. Applied multivariate data analysis (Oxford University Press, New York.

2. Barandovski L, Stafilov T, Šajn R, Frontasyeva M.V, Bačeva K., 2013. Air pollution study in Macedonia using a moss biomonitoring technique, ICP-AES and AAS. Macedonian Journal of Chemistry and Chemical Engineering, Vol. 32, No. 1, pp. 89-107.

3. Blagnytė R, Paliulis D., 2010. Research into Heavy Metals Pollution of Atmosphere Applying Moss as
Bioindicator: a Literature Review. Environmental Research, Engineering and Management, No. 4-54, p. 26-33.

4. Bradl H.B., 2005. Heavy Metals in the Environment. Interface science and technology - volume 6. University of Applied Sciences Trier Neubrucke, Germany. Elsevier academic press: Amsterdam - Boston - Heidelberg - London - New York - Oxford - Paris San Diego - San Francisco - Singapore - Sydney - Tokyo.

5. Canbay H.S., Doğantürk M. 2017. Metals Determination by Microwave Digestion ICP-OES of Some Dietary Supplements and Diet Products in Turkey. Eurasian Journal of Analytical Chemistry ISSN: 1306-3057 2017 12(1):45-53 DOI 10.12973/ ejac.2017.00143a.

6. Ceburnis D., Ruhling A. and Kvietkus K., 1996. Extended study of atmospheric heavy metal deposition in Lithuania based on moss analysis.

7. Cekova L.B., Frontasyeva S.S, Pavlov T., Stafilov E, Steinnes V, Urumov M., 2006. Air pollution studies in Macedonia using the moss biomonitoring technique, naa, aas, and gis technology. Intended for submission to: Environmental Monitoring and Assessment.

8. Chakrabortty Sh, Paratkar T., 2006. Biomonitoring of Trace Element Air Pollution Using Mosses. Aerosol and Air Quality Research, Vol. 6, No.3, pp. 247-258.

9. Chen J.P, Wang L.K, Wang M.H.S, Hung Y.T, Shammas N.K., 2017. Remediation of heavy metals in the environment. CRC Press Taylor \& Francis Group 6000 Broken Sound Parkway NW, Suite 300 Boca Raton, FL 33487-2742.

10. Ferenc S., Uher P., Spišiak J., Šimonová V., 2016. Chromium- and nickel-rich micas and associated minerals in listvenite from the Muránska Zdychava, Slovakia: products of hydrothermal metaso- 
matic transformation of ultrabasic rock. Journal of Geosciences 61, 239-254.

11. Fernandez J.A, Carballeira A., 2002. Biomonitoring metal deposition in Galicia (NW Spain) with mosses: factors affecting bioconcentration. Chemosphere 46-535-542.

12. Harmens H., Mills G., Hayes F., Norris D., et al. 2013. Air Pollution and Vegetation. ICP Vegetation Program me Coordination Centre, Centre for Ecology and Hydrology, Environment Centre Wales, Denial Road, Bangor, Gwinnett, LL57 2UW, UK http://icpvegetation.ceh.ac.uk.

13. Harmens H., Norris D. et al. 2008. Spatial and temporal trends in heavy metal accumulation in mosses in Europe 1990-2005. Programme Coordination Centre for the ICP Vegetation.

14. Herpin U., Siewers U., Markert B., Rosolen V., Breulmann G., Bernoux M., 2004. Second German Heavy-metal Survey by Means of Mosses, and Comparison of the First and Second Approach in Germany and other European Countries. Second Germany Heavy-metal Survey.

15. Khare K, 2012. Air Pollution - Monitoring, Modeling, Health and Control, p. cm. ISBN 978-953-51-0381-3.

16. Lazo P., Bekteshi L., Shehu A, 2013. Active Moss Biomonitoring Technique for Atmospheric Deposition of Heavy Metals in Elbasan City, Albania. Fresenius Environmental Bulletin. Volume 22 - No 1a.

17. Lucaciu A, Timofte L, Culicov O, Frontasyeva M.V, Oprea C, Man S.C, Mocanu R., Steinnes E., 2004. Atmospheric Deposition of Trace Elements in Romania Studied by the Moss Biomonitoring Technique. Journal of Atmospheric Chemistry 49: 533-548.

18. Markert B.A, Breure A.M, Zechmeister H.G., 2003. Bioindicators \& Biomonitors- Principles, Concepts and Applications. Trace Metals and other Contaminants in the Environment 6. Elsevier: Amsterdam - Boston - London - New York - Oxford - Paris San Diego - San Francisco - Singapore Sydney - Tokyo.

19. Mazzoni A.C., Lanzer R., Bordin J., Schäfer A., Wasum R., 2012. Mosses as indicators of atmospheric metal deposition in an industrial area of southern Brazil. Acta Botanica Brasilica 26(3): 553-558.
20. Nickel S., Hertel A, Pesch R., Schroder W., Steinnes E., Uggerud H.Th., 2014. Modeling and mapping spatio-temporal trends of heavy metal accumulation in moss and natural surface soil monitored 1990-2010 throughout Norway by multivariate generalized linear models and geostatistics. Atmospheric Environment.

21. Nriagu J.O. and Pacyna J.M. 2001. Quantitative assessment of worldwide contamination of air, water and soils by trace metals. National Water Researcher Institute, Box 5050, Burlington, Ontario L7R4A6, Canada. Norwegian Institute for Air Pollution Researcher, PO Box 64, N-2001Lillestrom, Norway.

22. Otvos E, Pazmandi T, Tuba Z., 2003. First national survey of atmospheric heavy metal deposition in Hungary by the analysis of mosses. The Science of the Total Environment 309; 151-160.

23. Steinnes E., 2005. Use of mosses as biomonitors of atmospheric deposition of trace elements. Department of Chemistry, Norwegian University of Science and Technology, Trondheim, Norway Abstract; XA0055146.

24. Vasconcelos M.T.S.D, Tavares H.M.F., 1998. Atmospheric metal pollution $\mathrm{Cr}, \mathrm{Cu}, \mathrm{Fe}, \mathrm{Mn}, \mathrm{Ni}, \mathrm{Pb}$ and $\breve{Z} \mathrm{Zn}$ in Oporto city derived from results for low-volume. Aerosol samplers and for the moss Sphagnum auriculatum bioindicator. The Science of the Total Environment $212-11$ Z -20 .

25. Vukojević V., Sabovljević M., Sabovljević A., Mihajlović N., Dražić G., Vučinić Z., 2010. Determination of Heavy Metal Deposition in the Country of Obrenovac (Serbia) Using Mosses as Bioindicators ii: Cadmium (Cd), Cobalt (Cd), and Chromium (Cr). Arch. Biol. Sci., Belgrade, 58 (2), 95-104.

26. Walker K. and Robert T., 2003. Terrestrial pollution in the Pechora basin, north-eastern European Russia. PhD thesis, University of Nottingham.

27. WHO 2007. Joint/Convention Task Force on the Health Aspects of Air Pollution. Health risks of heavy metals from long-range transboundary air pollution. Address requests about publications of the WHO Regional Office for Europe to: (http:// www.euro.who.int/pubrequest).

28. Huang Y. and Wu P., 2007. Statistical analysis and application of SAS. China Machine Press, Beijing. 